\title{
Antioxidant and Sensory Properties of New Beverage Formulations Composed of Palm Sugar, Aframomum melegueta, and Citric Acid
}

\author{
Fred Omon Oboh * (D) and Judith Imafidon \\ Department of Biological Sciences, Benson Idahosa University, P.M.B. 1100, Benin City 300211, Nigeria; \\ Pearlspridemsc15@yahoo.com \\ * Correspondence: foboh@biu.edu.ng; Tel.: +234-8036677636
}

Received: 3 July 2018; Accepted: 7 August 2018; Published: 10 August 2018

\begin{abstract}
Non-alcoholic still beverages were prepared from palm sugar, Aframomum melegueta pepper, and citric acid, and their physico-chemical, nutritional, antioxidative, and sensory properties were examined in order to determine their suitability as functional refreshing drinks of good nutritional value. Results for titrable acidity, $\mathrm{pH}$, 5-hydroxymethylfurfural (5-HMF), and antioxidant capacity (total phenolic content, 2,2-diphenyl-1-picrylhydrazyl radical scavenging activity, and reducing power), vitamin $C$, and carbohydrate content indicate that the beverage formulations had suitable chemical, nutritional, and antioxidant characteristics, and may be functional. Sensory evaluation of the formulations showed that they were acceptable and refreshing, thus presenting attractive ways of delivering the health benefits of oil palm sugar and Aframomum melegueta pepper.
\end{abstract}

Keywords: palm sugar; Aframomum melegueta seed extract; citric acid; beverage formulations; antioxidant capacity

\section{Introduction}

Beverages are refreshing drinks. They include the carbonated non-alcoholic, and the non-carbonated or "still" beverages, such as fruit drinks and fruit juices. Another important group of beverages is characterised by a common property of having an initially stimulating effect. These include alcoholic beverages, tea, coffee, and cocoa [1]. Beverages provide water, an important nutrient which is essential for good health and the prevention of dehydration; some contain carbohydrates to provide a sweet taste and as a source of calories to meet the body's energy requirements, and either natural or added vitamins, especially vitamin $C$, which are required daily for good health [1].

Palm sugar is the brown sweetener derived from palm sap, the white semi-translucent, sugary liquid obtained by tapping the stalk of the immature inflorescence of palm trees, the upper stem, or by tapping the felled trees. In Nigeria, palm sap is obtained mainly from the African oil palm (Elaeis guineensis Jacq) and the raffia (Raphia spp) palms [2] and is usually left to ferment, and drunk as such (palm wine-fresh, or pasteurised and bottled), or distilled to yield a strong liquor.

Palm sugar has been used as a traditional sweetener for thousands of years [2]. It is now gaining popularity globally because it is considered to be natural and healthy. One of the major health claims is its low glycemic index (GI) [3,4]. Low GI foods play an important role in the dietary management of diabetes, weight reduction, peak sport performance, and the reduction of risks associated with heart disease and hypertension [4-8]. Other findings are the high in vitro $\alpha$-amylase, $\alpha$-glucosidase, and ACE (angiotensin I-converting enzyme) inhibitory activity of brown sugar preparations (notably palm sugar), with potential for low cost dietary management of type 2-diabetes and hypertension [9]. Oil palm sugar is rich in the minerals $\mathrm{Ca}, \mathrm{Fe}$, and $\mathrm{K}$, and phenolic compounds; it exhibits considerable 
antimicrobial activity against clinical stains of Escherichia coli, Pseudomonas aeruginosa, Bacillus cereus, and Staphylococcus aureus [10].

The spice plant, Aframomum melegueta (Roscoe) K Schum (Zingiberaceae), is indigenous to the west coast of Africa from Guinea to Angola [11]. In Nigeria, its spicy seeds, known as alligator pepper, are commonly used, along with other spices, as ingredients in 'pepper soup', a peppery sauce, which may contain fish, chicken, beef, goat meat, or 'bush meat' (game). They are also chewed along with kolanut (Cola spp), a stimulant, and served along with the latter and alcoholic drinks to entertain guests [12]. In the food industry, alligator pepper forms an ingredient in non-alcoholic drinks, ice creams, and confectionery, and is used as flavouring in alcoholic beverages such as beer, wine, and gin [11]. The spice is rich in the minerals $\mathrm{Ca}, \mathrm{Mg}, \mathrm{Fe}, \mathrm{Zn}, \mathrm{K}$, and $\mathrm{Mn}$, with a modest content of protein and carbohydrate [13-15], and phytochemicals of medicinal value [16]; it features in traditional medicine [17-20]. However, although rich in minerals, with a modest content of protein and carbohydrate, alligator pepper is not usually considered to be important from the nutritional point of view, but is widely used as a spice and flavoring in food, and in ethno-medicine throughout the world for health benefits [21].

Several experiments have shown that Aframomium melegueta seed extracts may exert antioxidant and antibacterial effects [22,23], antidiarrheal action [24], anti-inflammatory properties [25], neuroprotective potentials due to the presence of quercetin and kaempferol [26], and manage erectile dysfunction [27]. The alkaloid fraction of the seeds exhibited ACE, acetyl cholinesterase (AChE), phosphodiesterase-5 (PDE-5), and arginase inhibitory activity; gas chromatographic analysis of the fraction revealed the presence of alkaloids, including senkirkine, angustifoline, undulatine, myristicin, safrole, lupanine, powelle, and indicine-N-oxide. The inhibition of these enzymes, according to the authors, could be the mechanism for the utilisation of the seeds for the management of erectile dysfunction in folk medicine [28]. The seed extracts have also been shown to contain four alpha-amylase and alpha-glucosidase inhibitory compounds, three arylalkanes (6-paradol, 6-gingerol, 6-shagaol), and a pentacyclic triterpene (oleanolic acid); of these, 6-gingerol and oleanolic acid exhibited higher inhibitory activity against these enzymes than the antidiabetic drug ascarbose [29,30]. Lawal et al. [31] reported the hypotensive and antihypertensive effects of $A$. melegueta seeds in both normotensive and hypertensive human subjects and suggested that these may be due to a central effect linked to peripheral vasodilatation. Gestational weight gain, which is one of the major causes of pre-eclampsia (elevated blood pressure during pregnancy), was reported to have been reduced by an aqueous extract of $A$. melegueta seeds [12].

Due to their medicinal properties, palm sugar and A. melegueta seeds may possess great potential for utilisation as a sweetener and flavouring in functional food and beverage formulations, thereby giving rise to value-added products and improving the income from their production and processing. In this study, oil palm sugar-sweetened, and A. melegueta pepper and citric acid-flavoured beverages, were prepared and their physico-chemical, antioxidant, and sensory properties were examined in order to determine their suitability as refreshing drinks of good nutritional value that may, in addition, provide other health benefits.

\section{Materials and Methods}

\subsection{Materials}

\subsubsection{Reagents}

2,2-diphenyl-1-picrylhydrazyl (DPPH), 5-HMF, gallic acid, and $\beta$-carotene were obtained from Sigma-Aldrich Co. St. Louis, MO, USA. Citric acid, thiobabituric acid, 2,6-dichlorophenol indophenol, Folin-Ciocalteu reagent, methanol, potassium ferricyanide, ascorbic acid, BHT (butylated hydroxytoluene), trichloroacetic acid, linoleic acid, Tween 20, sodium hydroxide, monosodium phosphate, disodium phosphate, phosphoric acid, and phenolphthalein were obtained from Merck, Darmstadt, Germany. All reagents were analytical grade. 


\subsubsection{Palm Sap}

Oil palm sap was obtained from the Nigerian Institute for Oil Palm Research near Benin City, Nigeria. The sap on analysis had a $\mathrm{pH}$ value of 3.73 and a titrable acidity value of $0.77 \%$.

\subsubsection{Alligator Pepper}

Dried A. melegueta fruits were obtained from the kolanuts section of Oliha Market, Benin City, Nigeria. The seeds were extracted from the dried fruits and further dried to a constant weight at $40{ }^{\circ} \mathrm{C}$ in a ventilated oven (UNISCOPE SM 9053 Laboratory oven, Surgifriend Medicals, Essex, England).

\subsection{Methods}

\subsubsection{Preparation of Palm Sugar}

Palm sugar was prepared as follows: Oil palm sap with a $\mathrm{pH}$ of 3.73 and titrable acidity of $0.77 \%$ was filtered through a cheese cloth. The filtrate was then boiled in an open pan at around $100{ }^{\circ} \mathrm{C}$ until it turned brown and viscous; the syrup was cooled and its volume was measured. One and a half litres $(1.5 \mathrm{~L})$ of the sap gave $150 \mathrm{~mL}$ of syrup. On cooling, the thin syrup turned into a viscous gel.

\subsubsection{Preparation of A. melegueta Pepper Cold Aqueous Extract}

Dried seeds (50 g) were crushed in a mortar and the pieces were further reduced to a fine powder using a laboratory blender. Twenty g of the powder was placed in a beaker and made up to $100 \mathrm{~mL}$ with distilled water. The mixture was stirred for $10 \mathrm{~min}$ and kept in the refrigerator at $4{ }^{\circ} \mathrm{C}$ for three days. It was then stirred again for $10 \mathrm{~min}$ and filtered through a cheese cloth; the extract was collected in a conical flask, covered with aluminium foil, and stored at $4{ }^{\circ} \mathrm{C}$ in the refrigerator.

\subsubsection{Beverage Formulation}

Formulations (A, B, C, and D) containing palm sugar, citric acid, alligator pepper extract, and water were prepared as stated in Table 1.

Table 1. Beverage formulations.

\begin{tabular}{ccccc}
\hline Beverage Ingredients & \multicolumn{4}{c}{ Formulations } \\
\cline { 2 - 5 } & A & B & C & D \\
Citric acid & - & $0.5 \mathrm{~g}$ & - & $0.5 \mathrm{~g}$ \\
A. melegueta seed extract & - & - & $10 \mathrm{~mL}$ & $10 \mathrm{~mL}$ \\
Palm sugar & $20 \mathrm{~g}$ & $20 \mathrm{~g}$ & $20 \mathrm{~g}$ & $20 \mathrm{~g}$ \\
Final volume (made up with distilled water) & $100.0 \mathrm{~mL}$ & $100.0 \mathrm{~mL}$ & $100.0 \mathrm{~mL}$ & $100.0 \mathrm{~mL}$ \\
\hline
\end{tabular}

\subsection{Analytical Procedure}

\subsubsection{Titrable Acidity}

Titrable acidity of sap and beverage preparations was determined by the titration of $5 \mathrm{~mL}$ samples with $0.1 \mathrm{~N} \mathrm{NaOH}$, using phenolphthalein as an indicator, to a definite pink end point. Oil palm syrup $(20 \mathrm{~g})$ was made up to $100 \mathrm{~mL}$ with previously neutralised distilled water. Aliquots $(5 \mathrm{~mL})$ were then titrated with $0.1 \mathrm{~N} \mathrm{NaOH}$ using phenolphthalein as an indicator. Titrable acidity was calculated as \% lactic acid.

\subsection{2. $\mathrm{pH}$}

The $\mathrm{pH}$ values of palm sap, palm sugar, and beverage formulations were measured using a Jenway Model $3505 \mathrm{pH}$ meter (Camlab, Over, Cambridge, UK). Palm sap or beverage formulation (10 mL) was 
read in triplicate. Palm syrup $(2.0 \mathrm{~g})$ was dissolved in $10.0 \mathrm{~mL}$ of distilled, deionised water and the $\mathrm{pH}$ of the solution was read in triplicate.

\subsubsection{Total Carbohydrate Content}

The total carbohydrate content of the oil palm syrup was determined using the anthrone method [32]. The syrup sample $(0.5 \mathrm{~mL}, 20 \%$ aqueous syrup solution) was hydrolysed in a boiling water bath for $3 \mathrm{~h}$ with $5 \mathrm{~mL}, 2.5 \mathrm{~N} \mathrm{HCl}$. The mixture was cooled to ambient temperature and neutralised with $\mathrm{Na}_{2} \mathrm{CO}_{3}$ until the effervescence stopped. The volume was made up to $100 \mathrm{~mL}$ and centrifuged. Aliquots of the supernatant $(0.5 \mathrm{~mL})$ and $0.2,0.4,0.6,0.8$, and $1 \mathrm{~mL}$ of the glucose standard $(0.1 \mathrm{mg} / \mathrm{mL})$ were measured into test tubes and made up to $1 \mathrm{~mL}$ with distilled water; aliquots $(4 \mathrm{~mL})$ of the anthrone reagent were added to each. A blank was prepared using distilled water instead of sample or glucose standard. The tubes were heated for $8 \mathrm{~min}$ in a boiling water bath (Thermo Scientific Precision, General Purpose, Thermo Fisher, Loughborough, UK), and then cooled rapidly. Absorbance was read at $630 \mathrm{~nm}$ using a uv-visible spectrophotometer (GENESYS 10S, Thermo Fisher Scientific, Madison, WI, USA) and the carbohydrate content was calculated from the standard graph.

\subsubsection{Glucose Content}

Glucose content of the syrup was determined by enzymatic oxidation with glucose oxidase reagent (Randox Laboratories Ltd., Antrim, UK.), according to Buba et al. [33]. The sample or standard $(20 \mu \mathrm{L})$ was allowed to react with $2.0 \mathrm{~mL}$ of the reagent, mixed well, and incubated for $10 \mathrm{~min}$ at $37^{\circ} \mathrm{C}$. The absorbance of the sample $\left(\mathrm{A}_{\text {sample }}\right)$ and standard $\left(\mathrm{A}_{\text {standard }}\right)$ was read at $540 \mathrm{~nm}$ against a reagent blank within $60 \mathrm{~min}$. Glucose was calculated as follows:

$$
\text { Glucose content }(\mathrm{mg} / \mathrm{dL})=\left(\mathrm{A}_{\text {sample }} / \mathrm{A}_{\text {standard }}\right) \times 100
$$

\subsubsection{Fructose Content}

This was determined using the resorcinol reagent method [34]. Resorcinol reagent was prepared by dissolving $1 \mathrm{~g}$ resorcinol and $0.25 \mathrm{~g}$ thiourea in $100 \mathrm{~mL}$ glacial acetic acid, and $1.0 \mathrm{~mL}$ of this was added to each of the $2 \mathrm{~mL}$ aliquots of a $20 \%$ solution of the syrup and the standard solutions (containing $0.2,0.4,0.6,0.8$, and $1.0 \mathrm{mg} / \mathrm{mL}$ fructose) and mixed thoroughly; dilute $\mathrm{HCl}(7 \mathrm{~mL})$ was then added. A reagent blank was also prepared along with the standard and treated in the same manner. The solutions were heated in a water bath at $80^{\circ} \mathrm{C}$ for $10 \mathrm{~min}$, cooled by immersion in tap water for $5 \mathrm{~min}$, and their absorbance was read at $520 \mathrm{~nm}$ within $30 \mathrm{~min}$. The fructose content was calculated from the standard graph.

\subsubsection{Sucrose Content}

Sucrose content was calculated as the difference between total carbohydrate content and the sum of the glucose and fructose content:

Sucrose content $=$ Total carbohydrate content $-($ glucose content + fructose content $)$

\subsubsection{5-Hydroxymethylfurfural (5-HMF) Content}

Hydroxymethylfurfural (5-HMF) concentration was determined spectrophotometrically according to Rattanathanalerk et al. [35]. Palm sugar $(10 \mathrm{~g})$ was dissolved in $50 \mathrm{~mL}$ deionized water and centrifuged at $5000 \mathrm{rpm}$ for $15 \mathrm{~min}$. Aliquots $(2 \mathrm{~mL}$ ) of the supernatant (or $2 \mathrm{~mL}$ of each beverage formulation) were placed in test tubes and $2 \mathrm{~mL}$ of $12 \%$ trichloroacetic acid (TCA) and $2 \mathrm{~mL}$ of $0.025 \mathrm{M}$ thiobabituric acid (TBA) were added and mixed thoroughly. The test tubes were placed in a water bath at $40{ }^{\circ} \mathrm{C}$ for $50 \mathrm{~min}$ and their contents were cooled to ambient temperature under water. The absorbance of the solutions was measured at $443 \mathrm{~nm}$. A calibration graph plotted using different concentrations of 5-HMF was used to quantify the 5-HMF concentration. Determinations were done in triplicate. 


\subsubsection{Determination of Ascorbic Acid Content}

Ascorbic acid content was determined titrimetrically by the 2,6-dichlorophenol indophenol method [36]. Briefly, standard indophenol solution was prepared by dissolving $50 \mathrm{mg}$ 2,6-dichlorophenol indophenol in $100 \mathrm{~mL}$ water and standard ascorbic acid solution was prepared by dissolving $50 \mathrm{mg}$ ascorbic acid in $60 \mathrm{~mL} \mathrm{20 \%} \mathrm{metaphosphoric} \mathrm{acid} \mathrm{and} \mathrm{diluting} \mathrm{to} 250 \mathrm{~mL}$ with distilled water. The dye was then standardized by titration with the standard ascorbic acid solution. To $50 \mathrm{~mL}$ sugar solution alone or with citric acid and/or A. melegueta extract, $25 \mathrm{~mL}$ of $20 \%$ metaphosphoric acid was added and the solution was diluted to $250 \mathrm{~mL}$ with distilled water. Aliquots $(10 \mathrm{~mL})$ were titrated with standard indophenol until a pink colour persisted for $15 \mathrm{~s}$. Vitamin C content was calculated as follows:

Vitamin $\mathrm{C}(\mathrm{mg} / 100 \mathrm{~mL})=$ Titre value $\times$ Vitamin $\mathrm{C} / \mathrm{mL}$ indophenol solution $\times 100$

\subsubsection{Qualitative Analysis of Phytochemicals}

The palm sugar and A. melegueta pepper extract were screened for the presence of alkaloids, flavonoids, glycosides, saponins, terpenoids, and tannins according to Evans [37].

\subsubsection{Determination of Antioxidant Capacity}

The antioxidant capacity of palm sugar, the A. melegueta pepper extract, and formulations was evaluated by determination of their total phenolic content, $\beta$-carotene bleaching antioxidant activity, 2,2-diphenyl-1-picrylhyderazyl (DPPH) radical scavenging activity, and reducing power.

\section{Total Phenolic Content}

Total phenolic content (TPC) was determined spectrophotometrically according to the method described by Singleton et al. [38]. Aliquots ( $100 \mu \mathrm{L}$ each) of sample ( $20 \%$ sugar solution or alligator pepper extract) and gallic acid standards (50,100, and 150 up to $500 \mathrm{mg} / \mathrm{L}$ ) were oxidized with $500 \mu \mathrm{L}$, $10 \%(\mathrm{v} / \mathrm{v})$ Folin-Ciocalteu reagent and neutralised with $400 \mu \mathrm{L}, 7.5 \%$ aqueous sodium carbonate. The reaction mixture was incubated in the dark for $40 \mathrm{~min}$ at ambient temperature and the absorbance was measured at $765 \mathrm{~nm}$. The total phenolic content was calculated from the calibration graph and expressed as $\mathrm{mg}$ gallic acid equivalent $(\mathrm{GAE}) / \mathrm{mL}$ of sample. Determinations were carried out in triplicate.

\section{$\beta$-Carotene Bleaching Antioxidant Activity}

The $\beta$-carotene bleaching antioxidant activity of palm sugar, A. melegueta pepper extract, the formulations, and BHT, was determined as follows [39]: Briefly, $\beta$-carotene solution $(0.2 \mathrm{mg}$ $\beta$-carotene $/ \mathrm{mL}$ of chloroform) was added to $0.02 \mathrm{~mL}$ of linoleic acid and $0.2 \mathrm{~mL}$ of Tween 20 in a round bottom flask. The chloroform was removed in a rotary evaporator at $40^{\circ} \mathrm{C}$. The resultant mixture was immediately diluted with $100 \mathrm{~mL}$ distilled water and mixed for $2 \mathrm{~min}$ to form an emulsion. A mixture prepared similarly without $\beta$-carotene was used as a blank. A control containing $0.2 \mathrm{~mL}$ of $70 \%$ ethanol instead of the sample was also prepared. Aliquots $(5 \mathrm{~mL})$ of the emulsion were transferred into test tubes, each of which contained $0.2 \mathrm{~mL}$ of each sample alone, and incubated at $50{ }^{\circ} \mathrm{C}$ in a water bath for $2 \mathrm{~h}$. Absorbance was read at $470 \mathrm{~nm}$ and the percentage antioxidant activity was calculated as follows:

$$
\text { Antioxidant activity }(\%)=1-\left[\left(\mathrm{A}_{0}-\mathrm{A}_{\mathrm{t}}\right) /\left(\mathrm{A}_{0 \mathrm{c}}-\mathrm{A}_{\mathrm{tc}}\right)\right] \times 100
$$

where $A_{0 s}$ and $A_{t s}$ are the absorbance values for the sample measured at time $t=0$ and $t=120 \mathrm{~min}$, respectively; and $\mathrm{A}_{0 \mathrm{c}}$ and $\mathrm{A}_{\mathrm{tc}}$ are the absorbance values for the control at $t=0$ and $t=120 \mathrm{~min}$, respectively. 


\section{2,2-Diphenyl-1-Picrylhydrazyl (DPPH) Radical Scavenging Activity}

The DPPH radical scavenging activity of the various preparations and BHT was evaluated according to the method of Tang et al. [40]. One $\mathrm{mL}$ of $0.2 \mathrm{mM}$ 2,2-diphenyl-1-picrylhydrazyl in absolute ethanol was placed in a test tube containing $4 \mathrm{~mL}$ of the sample. A control was prepared by adding $1 \mathrm{~mL}$ of DPPH solution to $4 \mathrm{~mL}$ of $70 \%$ ethanol. Following storage in the dark for $30 \mathrm{~min}$, the absorbance was read at $517 \mathrm{~nm}$.

Percentage free radical scavenging activity was calculated as follows:

$$
\text { DPPH radical scavenging activity }(\%)=1-\frac{\text { Absorbance of sample at } 517 \mathrm{~nm}}{\text { Absorbance of control at } 517 \mathrm{~nm}}
$$

\section{Reducing Power}

The reducing power of the palm sugar solution, BHT, and the formulations was determined according to the method of Oyaizu [41]. Aliquots $(100 \mu \mathrm{L})$ of these were mixed with $250 \mu \mathrm{L}, 200 \mathrm{mM}$ sodium phosphate buffer ( $\mathrm{pH}$ 6.6), and potassium ferricyanide $(250 \mu \mathrm{L}, 1 \%)$. The mixtures were incubated at $50{ }^{\circ} \mathrm{C}$ for $20 \mathrm{~min}$. Tricholoroacetic acid ( $250 \mu \mathrm{L}$ of a $10 \%$ solution) was added to each mixture and $250 \mu \mathrm{L}$ of this was mixed with $250 \mu \mathrm{L}$ distilled water and $0.5 \mathrm{~mL}, 0.1 \% \mathrm{FeCl}_{3}$. Absorbance was measured at $700 \mathrm{~nm}$. Ascorbic acid was used as the standard and results were expressed as $\mathrm{mg} \%$ Ascorbic Acid Equivalent [42].

\subsubsection{Sensory Evaluation of Samples}

A descriptive sensory analysis using verbal categorical scales was undertaken [43]. A description of colour, taste, odour, and texture of the formulations, based on sensory perception, was carried out by an untrained panel of six judges (three male and three female) selected from the final year biochemistry class of Benson Idahosa University, who apparently had no defect in their ability to perceive the characteristics examined. Labelled samples of the formulations (50 $\mathrm{mL}$ of each) in paper cups were placed on a table covered with white cardboard in a well- lit and ventilated room. Prior to inspection of samples, panellists were provided with a sheet containing the following descriptions of characteristics and were asked to record those which were closest to their observations (Table 2).

Table 2. Descriptive sensory evaluation sheet.

\begin{tabular}{|c|c|c|c|c|c|}
\hline Colour & Colourless & Pale Yellow & Light Brown & Brown & Deep Brown \\
\hline Smell & Bland & Palm sap & Orange juice & $\begin{array}{l}\text { Orange juice } \\
+ \text { palm sap }\end{array}$ & Spicy, orange juice \\
\hline Taste & Bland & Sweet & Sweet and sour & $\begin{array}{l}\text { Sweet and } \\
\text { peppery }\end{array}$ & $\begin{array}{l}\text { Sweet, sour peppery } \\
\text { and astringent }\end{array}$ \\
\hline $\begin{array}{l}\text { Mouth feel (feel between } \\
\text { tongue and palate) }\end{array}$ & Light like water & Light and oily & $\begin{array}{l}\text { Light, with friction } \\
\text { (slightly abrasive) }\end{array}$ & $\begin{array}{l}\text { Viscous and } \\
\text { fatty (sticky) }\end{array}$ & Viscous andgrainy \\
\hline Like/dislike & Dislike & Like, just a little & Like averagely & Like much & Like very much \\
\hline $\begin{array}{c}\text { Refreshing (pleasantly } \\
\text { new, different and } \\
\text { interesting): Yes/no }\end{array}$ & $\begin{array}{l}\text { Different from } \\
\text { the familiar, } \\
\text { and unpleasant }\end{array}$ & $\begin{array}{c}\text { Different, not } \\
\text { unpleasant, but not } \\
\text { interesting either. }\end{array}$ & $\begin{array}{l}\text { Interesting, pleasant, } \\
\text { but not new }\end{array}$ & $\begin{array}{l}\text { New, pleasant, } \\
\text { but just average }\end{array}$ & $\begin{array}{c}\text { Pleasantly new, } \\
\text { different and interesting }\end{array}$ \\
\hline
\end{tabular}

\subsection{Statistical Analysis}

Experimental replicates within individual experiments were averaged and expressed as mean $\pm \mathrm{SD}$. Comparisons between means were determined by an unpaired Student's $t$ test with two-tailed $p$-values reported, employing Microsoft Excel 2007. Each experiment was replicated three times with comparable results. Results with $p<0.05$ were regarded as statistically significant. 


\section{Results and Discussion}

Lactic acid produced by lactic acid bacteria has been reported as the main organic acid responsible for the acidity of palm sap [44-47], palm syrup, and maple syrup [48]. In their study of the growth of yeast, lactic, and acetic acid bacteria in oil palm (E. guineensis) sap during the tapping of felled trees and its fermentation, Amoa-Awua et al. [44] found that Lactobacillus plantarum and Leuconostoc mesenteroides were the dominant lactic acid bacteria on the first day, while acetic acid bacteria were only isolated after the third day, when levels of alcohol had become substantial. In a more recent study of microbiological and organic acid changes occurring in palm wine tapping of two oil palm varieties (dura and tenera), Karamoko et al. [49] concluded that lactic acid bacteria were largely responsible for the rapid acidification of the product as acetic acid bacteria were not isolated in the palm wine samples on the first days of tapping. Hence, a modest titrable acidity, with a corresponding low $\mathrm{pH}$ (such as that obtained in this study), indicates this initial fermentation step of palm sap during tapping.

The physico-chemical characteristics of the oil palm syrup used in the formulation are shown in Table 3.

Table 3. Chemical properties of oil palm syrup.

\begin{tabular}{lc}
\hline \multicolumn{1}{c}{ Characteristic } & Value \\
\hline Total carbohydrate (\%) & $66.22 \pm 4.44$ \\
Sucrose (\%) & $60.25 \pm 4.41$ \\
Glucose (\%) & $3.46 \pm 0.00$ \\
Fructose (\%) & $2.53 \pm 0.17$ \\
Titrable acidity (\%) & $3.60 \pm 0.00$ \\
$\mathrm{pH} *$ & $3.48 \pm 0.01$ \\
Vitamin C (mg \%) & $170.0 \pm 0.05$ \\
5-Hydroxymethylfurfural (mmol/kg) & $1.009 .0 \pm 0.002$ \\
\hline \multicolumn{2}{c}{ * Value for a 20\% solution of the syrup. }
\end{tabular}

Eze and Ogan [50] determined the sugar composition of unfermented (freeze-tapped) sap from oil palm trees in the plantations of the Nigerian Institute for Oil Palm Research, Benin City, which had a pH of 6.60 , total sugar content of $11.61 \%$ (with sucrose accounting for $10.59 \%$, and glucose and fructose 0.49 and $0.53 \%$, respectively). Subsequent fermentation of the sap at $36-37{ }^{\circ} \mathrm{C}$ resulted in a rapid fall in sugar content to 10.46 , and then $6.18 \%$, with a corresponding decrease in $\mathrm{pH}$ from 6.60 to 5.14 and then 3.97 in 3 and $9 \mathrm{~h}$, respectively, and a rapid rise in titrable acidity from 2.1 to 12.2 and then to $53 \mathrm{mmol} \mathrm{H}^{+} / \mathrm{L}$. In this study, the evaporation of palm sap to a tenth of its volume yielded syrup with a sugar content of $66.22 \%$, corresponding to a sap sugar content of about $6.62 \%$, indicating that it had undergone some lactic fermentation in the process of tapping and handling, resulting in a decrease in sugar content and a corresponding increase in titrable acidity to a value of 0.77 , and decrease in $\mathrm{pH}$ to 3.73 (similar to the value of 3.97 recorded for oil palm sap and a sugar content of $6.18 \%$ previously found [50]). Also, sucrose was the dominant sugar and glucose and fructose were minor constituents; sugar content was relatively high, in agreement with the fact that the sap was tapped in the morning and preserved in ice shortly after collection, in order to minimize fermentation until its evaporation to produce the syrup.

The syrup had a considerable titrable acidity and vitamin $C$ content. Titrable acids, as well as vitamin C, provide a desirable tart flavour in foods, and their presence gives the distinct impression of fresh fruit. Karamoko et al. [49] detected several organic acids in freshly collected Elaeis guineensis palm sap; these included oxalic, citric, tartaric, malic, ascorbic, formic, lactic, propionic, and acetic acids. However, according to the authors, three of these-oxalic, acetic, and propionic-were not native to the exudates, but were produced by adventitious organisms during the tapping process. The concentration of these organic acids in the syrup contributes to its flavour; according to Eze and Ogan [50], titrable acidity is an important determinant factor for the sour taste in wines. Vitamin C 
is an antioxidant, which acts by donating hydrogen atoms to molecular oxygen. In doing so, it is preferentially oxidized. This ability to scavenge oxygen protects the flavour as well as the colour of an array of beverages [1]. Vitamin C plays an important role in the synthesis of collagen, by preventing the oxidation of ferrous iron cofactor of prolyl hydroxylase, thus offering protection against scurvy. Increased intake of this vitamin is associated with a reduced risk of chronic diseases such as cancer, cardiovascular disease, and cataract, probably through antioxidant mechanisms [51].

Hydroxymethyl furfural (5-HMF) is a decomposition product of fructose. It is formed during the heat treatment of foods (such as in the evaporation of palm sap to produce sugar) and is an indicator of the extent of this; it also contributes to the flavour of foods and may function as an antioxidant [52].

The phytochemicals present in the oil palm sugar and the aqueous extract of $A$. melegueta pepper are shown in Table 4.

Table 4. Phytochemical groups present in oil palm sugar and alligator pepper aqueous extract.

\begin{tabular}{ccc}
\hline Phytochemical Group & Oil Palm Sugar & A. melegueta Pepper Aqueous Extract \\
\hline Alkaloids & $-{ }^{\mathrm{a}}$ & $+\mathrm{b}$ \\
Tannins & - & + \\
Saponins & + & + \\
Glycosides & + & + \\
Terpenoids & - & + \\
Flavonoids & + & + \\
\hline
\end{tabular}

The alligator pepper extract contained alkaloids, tannins, saponins, glycosides, terpenoids, and flavonoids; the palm sugar only contained glycosides, flavonoids, and saponins. These phytochemical groups contain dietary phytochemicals known to exhibit biological activity resulting in potential health benefits [27-29].

Antioxidant capacity values for the beverage ingredients—oil palm sugar solution and A. melegueta pepper extract-are given in Table 5. Included for comparison are values for butylated hydroxyquinone (BHT), a highly potent synthetic antioxidant used in foods.

Table 5. Antioxidant capacity values for oil palm sugar solution, A. melegueta pepper extract, and BHT.

\begin{tabular}{|c|c|c|c|}
\hline Characteristic & Oil Palm Sugar ${ }^{a}$ & $\begin{array}{c}\text { A. melegueta Pepper } \\
\text { Aqueous Extract }\end{array}$ & BHT $^{b}$ \\
\hline Total phenolic content $\left(\mathrm{mg} \mathrm{GAE}^{\mathrm{c}} / \mathrm{mL}\right)$ & $0.216 \pm 0.010$ & $0.130 \pm 0.005$ & - \\
\hline DPPH radical scavenging activity (\%) & $28.31 \pm 0.99$ & $12.40 \pm 0.20$ & $84.07 \pm 2.55$ \\
\hline$\beta$-carotene bleaching antioxidant activity $(\%)$ & $26.58 \pm 2.42$ & $51.27 \pm 0.57$ & $72.00 \pm 3.62$ \\
\hline Reducing power $\left(\mathrm{mg} \% \mathrm{AAE}^{\mathrm{d}}\right)$ & $39.69 \pm 0.77$ & - & $5.12 \pm 0.02$ \\
\hline
\end{tabular}

Values are expressed as mean $\pm \operatorname{SEM}(n=3) .{ }^{\text {a }} 20 \%$ syrup in distilled water; ${ }^{\mathrm{b}} 0.02 \%$ in $70 \%$ ethanol; ${ }^{\mathrm{c}}$ GAE: Gallic

Acid Equivalent. ${ }^{d}$ AAE: Ascorbic Acid Equivalent.

The palm sugar and solution and A. melegueta pepper extract had a considerable total phenolic content. The total phenolic content assay by the Folin-Ciocalteu reagent is also a measure of the reducing capacity of a substance [53], and would include, in addition to phenolic compounds, non-phenolic compounds, including vitamin C, 5-HMF, and Maillard reaction products. Both solutions therefore exhibited a considerable reducing capacity. Although there are numerous phytochemicals consumed in the diet, polyphenols constitute the largest group, and have attracted much attention due to their antioxidant properties. The antioxidant activity of regularly consumed fruits and vegetables reflects their phenolic and vitamin $C$ composition [54,55].

Compared with BHT, which had a high value, the palm sugar solution exhibited modest DPPH radical scavenging activity, while the aqueous $A$. melegueta extract had a lower level of activity, but a high $\beta$-carotene bleaching activity. The palm sugar solution exhibited moderate $\beta$-carotene 
bleaching activity; both the sugar solution and the pepper extract had lower values than that of BHT. The palm sugar exhibited a high reducing power, but BHT had a relatively low value.

Some nutritional characteristics of beverage formulations containing the palm sugar, alligator pepper, and citric acid are shown in Table 6. All the preparations had an equal carbohydrate content.

Table 6. Chemical characteristics of beverage formulations.

\begin{tabular}{ccccc}
\hline Characteristic & $\begin{array}{c}\text { Palm Sugar } \\
\text { + Distilled Water }\end{array}$ & $\begin{array}{c}\text { Palm Sugar } \\
\text { + Citric Acid } \\
\text { + Water }\end{array}$ & $\begin{array}{c}\text { Palm Sugar } \\
\text { + A. melegueta Pepper } \\
\text { Extract + Water }\end{array}$ & $\begin{array}{c}\text { Palm Sugar + Citric } \\
\text { Acid + A. melegueta } \\
\text { Pepper Extract + Water }\end{array}$ \\
\hline Total carbohydrate (\%) ${ }^{\text {a }}$ & $13.28 \pm 0.89$ & $13.28 \pm 0.89$ & $13.28 \pm 0.89$ & $13.28 \pm 0.89$ \\
Titrable acidity (\%) & $0.72 \pm 0.00$ & $0.79 \pm 0.00$ & $0.19 \pm 0.01$ & $0.80 \pm 0.02$ \\
pH & $3.48 \pm 0.01$ & $3.12 \pm 0.01$ & $3.51 \pm 0.01$ & $3.14 \pm 0.01$ \\
Vitamin C (mg/100 mL) & $34.00 \pm 0.10$ & $34.00 \pm 0.10$ & $36.00 \pm 0.00$ & $35.00 \pm 0.00$ \\
5-Hydroxymethyl furfural & $201.70 \pm 0.45$ & $202.15 \pm 0.53$ & $201.87 \pm 0.27$ & $202.81 \pm 0.95$ \\
(5-HMF), $\mu \mathrm{mol} / \mathrm{L}$ & & & & \\
\hline
\end{tabular}

${ }^{a}$ Calculated from the total carbohydrate content value in Table 3.

The addition of citric acid to the palm sugar solution resulted in a slight increase in titrable acidity and a corresponding decrease in $\mathrm{pH}$. Addition of the A. melegueta extract to the palm sugar solution decreased its titrable acidity, with a slight increase in $\mathrm{pH}$ to 3.51 , indicating the alkalinity of, and some neutralisation by, the extract. The combination of citric acid, palm sugar, and A. melegueta pepper extract had a higher titrable acidity, and lower $\mathrm{pH}$, with these values being similar to the values for the sugar and citric acid formulation. The addition of citric acid did not cause large shifts in the $\mathrm{pH}$ values, indicating the ability of the palm sugar to buffer the effect of this acid, thereby preventing a sharp increase in acidity and the production of a very sour taste. Eze and Ogan [50] observed a similar phenomenon in (the increasing organic acid content of) fermenting oil palm sap, which they attributed to the efficient buffering of the protons by the weak organic acids produced. Formulations containing the alligator pepper extract had a vitamin $C$ content $(36.00$ and $35.00 \mathrm{mg} / 100 \mathrm{~mL}$ ) similar to those that did not (34 mg/100 mL); thus, each contained 57 to $60 \%$ of the recommended dietary allowance (RDA) of $60 \mathrm{mg} / 100 \mathrm{~mL}$ for the vitamin [51], with content comparable to those of mandarin, grapefruit, and lemon citrus varieties [56].

Vitamin C stability is inversely proportional to the $\mathrm{pH}$ of the medium in which it is present [57] and this compound, when present in juices of a lower $\mathrm{pH}$, tends to be less susceptible to degradation. The optimum stability of ascorbic acid in the presence of oxidizing agents has been exhibited at a $\mathrm{pH}$ of about 3.0-4.5 [58], a range that includes the values for all the formulations in this study. The presence of heavy metals such as iron and copper in a beverage system can greatly accelerate vitamin $C$ degradation, with a resulting decrease in beverage quality. The use of citric acid can promote vitamin C stability by rendering various heavy metals unavailable for the catalysis of its oxidation [1]. 5-HMF values were similar for all the formulations, indicating that this compound was mainly contributed by the palm sugar.

The antioxidant capacities of the palm sugar solution and formulations are shown in Table 7.

Table 7. Antioxidant capacity of beverage formulations.

\begin{tabular}{|c|c|c|c|c|}
\hline Characteristic & $\begin{array}{c}\text { Palm Sugar } \\
\text { + Distilled Water }\end{array}$ & $\begin{array}{c}\text { Palm Sugar + Citric } \\
\text { Acid + Water }\end{array}$ & $\begin{array}{c}\text { Palm Sugar } \\
+ \text { A. melegueta Pepper } \\
\text { Extract }+ \text { Water }\end{array}$ & $\begin{array}{c}\text { Palm Sugar + A. melegueta } \\
\text { Pepper Extract + Citric } \\
\text { Acid + Water }\end{array}$ \\
\hline $\begin{array}{c}\text { DPPH radical } \\
\text { scavenging activity }(\%)\end{array}$ & $28.31 \pm 0.99^{a}$ & $27.58 \pm 0.79^{a}$ & $54.10 \pm 2.09^{b}$ & $79.83 \pm 0.60^{c}$ \\
\hline $\begin{array}{l}\text { Reducing power mg \% } \\
\text { ascorbic acid } \\
\text { equivalent (AAE) }\end{array}$ & $39.69 \pm 0.77^{a}$ & $39.91 \pm 1.10^{a}$ & $41.35 \pm 2.56^{\mathrm{a}}$ & $45.19 \pm 0.19^{b}$ \\
\hline
\end{tabular}


Beverages containing palm sugar alone, and with added citric acid, exhibited a similar DPPH radical scavenging activity and reducing power; that which contained A. melegueta pepper and palm sugar had a higher DPPH radical scavenging activity, but similar reducing power. The higher DPPH radical scavenging activity was due to the additional phenolic content provided by the alligator pepper extract $(0.013 \mathrm{mg} \mathrm{GAE} / \mathrm{mL}$, from a 10-fold dilution in the formulation), and lower acidity than for the beverage containing palm sugar alone. Higher DPPH radical quenching in less acidic media has also been observed in tea infusions [59], and it was postulated that the change in hydrogen ion concentration caused the change of the mechanism of the scavenging process of DPPH radicals by phenolic compounds, with the decrease in $\mathrm{pH}$ leading to the domination of the Proton Coupled Electron Transfer (PC-ET) mechanism [60].

The combination of citric acid, palm sugar, and alligator pepper exhibited the highest DPPH radical scavenging activity and reducing power. Citric acid has several important functions in beverages, including flavour modification, $\mathrm{pH}$ control, the chelation of metals, and catalysis of the conversion of sucrose to invert sugar [1]. Since citric acid had no significant effect on the antioxidant capacity when added to the palm sugar alone, and the synergistic effect observed when it was added to the combination of the palm sugar and A. melegueta extract probably resulted from its chelation of pro-oxidant metal(s) in the sugar and pepper extract, thereby making them unavailable for the catalysis of oxidative reactions. Indeed, Okwu [18] reported the presence of the pro-oxidant metals iron $(1.80 \pm 0.22 \mathrm{mg} / 100 \mathrm{~g})$ and copper $(0.63 \pm 0.22 \mathrm{mg} / 100 \mathrm{~g})$, and Odebunmi et al. [13] found an iron content of $37.80 \pm 0.16 \mathrm{mg} / \mathrm{kg}$ in alligator pepper seeds. Oboh et al. [10] reported an iron content of $2.90 \pm 0.14 \mathrm{mg} / 100 \mathrm{~g}$ in oil palm syrup. A higher DPPH scavenging activity, resulting from the removal of proxidant metal ions from tea infusions, has been observed by previous workers [59].

The DPPH [61] and $\mathrm{pH}[62,63]$ values of a number of commercial ready-to-drink beverages, which base their marketing strategies on antioxidant potency and are regarded as functional drinks [61], and values for the palm sugar- $A$. melegueta pepper-citric acid beverage formulations, are shown in Table 8.

Table 8. Comparison of DPPH and $\mathrm{pH}$ of formulations with reported values for beverages with reported health benefits.

\begin{tabular}{ccc}
\hline Beverage & $\begin{array}{c}\text { Average DPPH Radical } \\
\text { Scavenging Activity (\% Inhibition) }\end{array}$ & pH \\
\hline Palm sugar + A melegueta pepper + citric acid + water & $79.83 \pm 0.60^{\mathrm{a}}$ & $3.14 \pm 0.01^{\mathrm{a}}$ \\
Palm sugar + A. melegueta pepper + water & $54.10 \pm 2.09^{\mathrm{a}}$ & $3.51 \pm 0.01^{\mathrm{a}}$ \\
Pomegranate & $50.10 \pm 1.90^{\mathrm{b}}$ & $2.93-3.20^{\mathrm{c}}$ \\
Red wine & $35.2 \pm 2.2^{\mathrm{b}}$ & $3.30-3.50^{\mathrm{d}}$ \\
Palm sugar + water & $28.30 \pm 0.99^{\mathrm{a}}$ & $3.48 \pm 0.01^{\mathrm{a}}$ \\
Concord grape juice & $28.20 \pm 6.10^{\mathrm{b}}$ & $2.80-3.00^{\mathrm{c}}$ \\
Palm sugar + citric acid + water & $27.58 \pm 0.79^{\mathrm{a}}$ & $3.12 \pm 0.01^{\mathrm{a}}$ \\
Iced green tea & $22.30 \pm 2.60^{\mathrm{b}}$ & $3.72 \pm 0.01^{\mathrm{c}}$ \\
Blueberry juice & $20.60 \pm 1.40^{\mathrm{b}}$ & $3.11-3.33^{\mathrm{c}}$ \\
Cranberry juice & $19.20 \pm 0.60^{\mathrm{b}}$ & $2.30-2.50^{\mathrm{c}}$ \\
Acai juice & $18.3 \pm 1.2^{\mathrm{b}}$ & $2.05-3.50^{\mathrm{c}}$ \\
Orange juice & $12.70 \pm 1.0^{\mathrm{b}}$ & $3.30-4.19^{\mathrm{d}}$ \\
\hline
\end{tabular}

${ }^{\text {a }}$ This study, ${ }^{\mathrm{b}}[60],{ }^{\mathrm{c}}[61],{ }^{\mathrm{d}}[62]$.

The palm sugar and the palm sugar and citric acid solutions had higher DPPH assay values than iced green tea, blueberry juice, cranberry juice, acai palm juice, and orange juice. The palm sugar and alligator pepper formulation had a higher value than pomegranate juice and red wine. They all had acid $\mathrm{pH}$ values ranging from 2.05 to 4.19 , which lie within the range for natural fruit juices. Thus, based on this favourable comparison, coupled with the high phenolic (and other phytochemicals) content and demonstrated health benefits of palm sugar and aqueous extracts of A. melegueta seeds, these beverages incorporating them may be regarded as functional.

The results of the sensory evaluation of the different formulations are presented in Table 9. 
Table 9. Descriptive sensory characteristics of formulations.

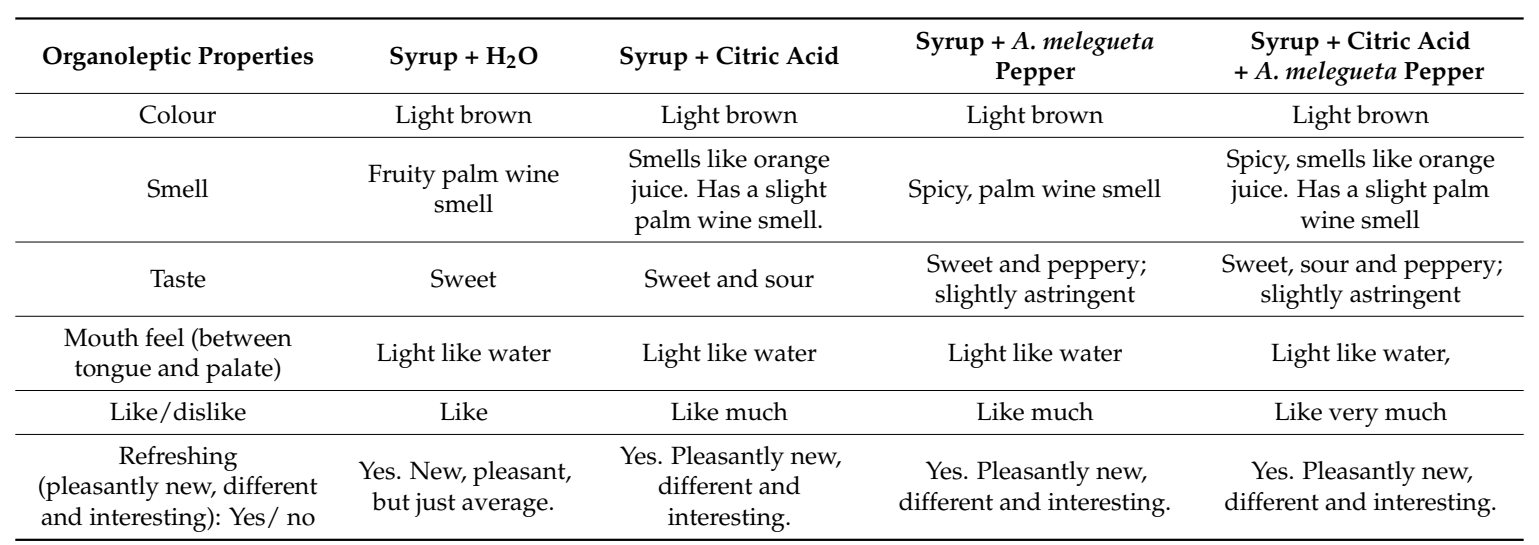

All the formulations had a light brown colour. The palm sugar solution had a fruity palm wine smell. Citric acid is the preferred acidulant in the beverage industry because its pleasant sour taste and thirst quenching effect are characteristic of citrus fruits [1]. The addition of citric acid altered the taste and smell of the palm sugar solution. It introduced an orange juice smell, which was stronger than the fruity palm wine smell, as well as a pleasant sour taste and (possibly) protection for vitamin C. The formulation containing the alligator pepper extract and palm sugar had a spicy palm sap smell, and that containing palm sugar, alligator pepper, and citric acid had a spicy, orange juice, and a slight palm sap smell. The palm sugar solution alone had a sweet taste, while the combination of sugar with citric acid had a sour-sweet taste. The palm sugar and A. melegueta pepper formulation was sweet and slightly peppery, and the sugar solution containing citric acid and alligator pepper extract was sweet, sour, and slightly peppery. The formulations had a light and smooth mouth feel; in addition, formulations containing alligator pepper extract were mildly astringent. All the sensory characteristics observed were pleasant. The beverage formulation containing palm sugar, alligator pepper, and citric acid (which had the highest DPPH radical scavenging activity and reducing power) was the preferred product based on the sensory evaluation. Thus, the beverage formulations present pleasant ways for the delivery of the medicinal constituents of oil palm syrup and A. melegueta pepper, and the associated health benefits.

\section{Conclusions}

Non-alcoholic, non-carbonated drinks were formulated from sugar derived from the sap of the African oil palm (Elaeis guineensis Jacq) tree, the aqueous extract of Aframomum melegueta seeds, and citric acid. Their antioxidant capacity, and carbohydrate, vitamin C, and phytochemicals content, coupled with their pleasant organoleptic characteristics, indicate that they may be suitable for use as refreshing functional beverages.

Author Contributions: Conceptualization, F.O.O.; Data curation, F.O.O.; Formal analysis, F.O.O. and J.I.; Investigation, F.O.O. and J.I.; Methodology, F.O.O.; Supervision, F.O.O.; Validation, F.O.O.; Writing-original draft, J.I.; Writing—review \& editing, F.O.O.

Funding: This research received no external funding.

Conflicts of Interest: The authors declare no conflict of interest.

\section{References}

1. Miles Inc. Miles Guide to Citric Acid and Other Beverage Ingredients. A Technical Bulletin; Biotechnology Products Division, Miles Inc.: Elkhart, IN, USA, 1987; p. 26.

2. Francisco-Ortega, J.; Zona, S. Sweet sap from palms, a source of beverages, alcohol, vinegar, syrup and sugar. Vieraea 2013, 41, 91-113. 
3. Trinidad, T.P.; Mallillin, A.C.; Sagum, R.S.; Encabo, R.R. Glycemic index of commonly consumed carbohydrate foods in the Philippines. J. Funct. Foods 2010, 2, 271-274. [CrossRef]

4. Strikaeo, K.; Tonga, R. Effects of sugarcane, palm sugar, coconut sugar and sorbitol on starch, digestibility and physicochemical properties of heat based foods. Int. Food Res. J. 2015, 22, 923-929.

5. Jenkins, D.J.A.; Wolever, T.M.S.; Taylor, R.H. Glycemic index of foods: A physiological basis for carbohydrate exchange. Am. J. Clin. Nutr. 1981, 34, 362-366. [CrossRef] [PubMed]

6. Foster-Powell, K.; Miller, J.B. International tables of glycemic index. Am. J. Clin. Nutr. 1995, 62, 871S-890S. [CrossRef] [PubMed]

7. Foster-Powell, K.; Holt, S.H.; Brand-Miller, J.C. International table of glycemic index and glycemic load values. Am. J. Clin. Nutr. 2002, 76, 5-56. [CrossRef] [PubMed]

8. Jenkins, D.J.A.; Kendall, C.W.C.; Augustin, L.S.A.; Franceschi, S.; Hamidi, M.; Marchie, A.; Jenkins, A.L.; Axelsen, M. Glycemic index: Overview of implications in health and disease. Am. J. Clin. Nutr. 2002, 76, 266S-273S. [CrossRef] [PubMed]

9. Ranilla, L.G.; Kwon, Y.I.; Genovese, M.I.; Lajolo, F.M.; Shetty, K. Antidiabetes and antihypertension potential of commonly consumed carbohydrate sweeteners using in vitro models. J. Med. Food 2008, 11, 337-348. [CrossRef] [PubMed]

10. Oboh, F.O.; Iyare, L.; Idemudia, M.; Enabulele, S. Physico-chemical and nutritional characteristics, and antimicrobial activity of oil palm syrup, raffia palm syrup and honey. IOSR J. Pharm. Biol. Sci. 2016, 11, 73-78.

11. Borget, M. Spice Plants. In The Tropical Agiculturalist Series; Coste, R., Ed.; The Centre for Agricultural and Rural Development (CTA), Macmillan Press Ltd.: London/Basingstoke, UK, 1993; p. 114.

12. Inegbenebor, U.; Ebomoyi, M.I.; Onyia, K.A.; Amadi, K.; Aigbiremolen, A.E. Effect of alligator pepper (Zingiberaceae; Aframomum melegueta) on gestational weight gain. Niger. J. Physiol. Sci. 2009, 24, 165-169. [PubMed]

13. Odebunmi, E.O.; Oluwaniyi, O.O.; Awolola, G.V.; Adediji, O.D. Proximate and nutritional composition of kola nut (Cola nitida), bitter cola (Garcinia cola) and alligator pepper. Afr. J. Biotechnol. 2009, 8, 308-310.

14. Borquaye, L.S.; Darko, G.; Laryea, M.K.; Gasu, E.N.; Amponsah, N.A.A.; Appiah, E.N. Nutritional and anti-nutrient profiles of some Ghanaian spices. Cogent Food Agric. 2017, 3, 1-12. [CrossRef]

15. Ogbunugafor, H.A.; Ugochukwu, C.G.; Kyrian-Ogbonna, A.E. The role of spices in nutrition and health: A review of three popular spices used in Southern Nigeria. Food Qual. Saf. 2017, 1, 171-185. [CrossRef]

16. Amadi, S.W.; Zhang, Y.; Wu, G. Research progress in phytochemistry and biology of Aframomum species. Pharm. Biol. 2016, 54, 2761-2770. [CrossRef] [PubMed]

17. Olowokudejo, J.D.; Kariri, A.B.; Travih, V.A. An ethnobotanical survey of herbal markets and medicinal plants in Lagos State of Nigeria. Ethnobot. Leafl. 2005, 1, 851-865.

18. Okwu, D.E. Phytochemicals, vitamins and mineral contents of two Nigerian medicinal plants. Int. J. Mol. Med. Adv. Sci. 2005, 1, 375-381.

19. Etundi, C.B.; Kuate, D.; Ngondi, J.L.; Oben, J. Anti-amylase, anti-lipase and antioxidant effects of aqueous extracts of some Cameroonian species. J. Nat. Products 2010, 3, 165-171.

20. Adefegha, S.A.; Oboh, G. Phytochemistry and mode of action of some tropical spices in the management of type 2 diabetes and hypertension. Afr. J. Pharm. Pharmacol. 2013, 7, 332-346. [CrossRef]

21. Adefegha, S.A.; Oboh, G.; Adefegha, O.M.; Henle, T. Alligator pepper/grain of paradise (Aframomum melegueta) modulates angiotensin-I converting enzyme activity, lipid profile and oxidative imbalances in a rat model of hypercholesterolemia. Pathophysiology 2016, 23, 191-202. [CrossRef] [PubMed]

22. Adegoke, G.O.; Makinde, O.; Falade, K.O.; Uzo-Peters, P.I. Extraction and characterization of antioxidants from Aframomum melegueta and Xylopia aethiopica. Eur. Food Res. Technol. 2003, 216, 526-528. [CrossRef]

23. Ogbonna, C.N.; Nozaki, K.; Yajima, H. Antimicrobial activity of Xylopia aethiopica, Aframomum melegueta and Piper guineense ethanolic extracts and the potential of using Xylopia aethiopica to preserve fresh orange juice. Afr. J. Biotechnol. 1998, 12, 1993-1998. [CrossRef]

24. Umukoro, S.; Ashorobi, R.B. Pharmacological evaluation of the antidiarrheal activity of Aframomum melegueta seed. West Afr. J. Pharmacol. Drug Res. 2003, 19, 51-54.

25. Umukoro, S.; Ashorobi, R.B. Further evaluation of the anti-inflammatory activity of Aframomum melegueta seed extract and its possible mechanism of action. Niger. J. Health Biomed. Sci. 2005, 4, 35-39. [CrossRef] 
26. Adefegha, S.A.; Oboh, G. Acetylcholinesterase (AChE) inhibitory activity, antioxidant properties and phenolic composition of two Aframomum species. J. Basic Clin. Physiol. Pharmacol. 2012, 23, $153-161$. [CrossRef] [PubMed]

27. Mbongue, G.Y.F.; Kamtchouing, P.; Dimo, T. Effects of the aqueous extract of dry seeds of Aframomum melegueta on some parameters of the reproductive functions of mature male rats. Andrologia 2012, 44, 53-58. [CrossRef] [PubMed]

28. Adefegha, S.A.; Oboh, G.; Okeke, B. Comparative effects of alkaloid extracts from Aframomum melegueta (alligator pepper) and Aframomum danielli (bastered melegueta) on enzymes relevant to erectile dysfunction. J. Diet. Suppl. 2017, 14, 542-552. [CrossRef] [PubMed]

29. Ajaiyeoba, E.O.; Ekundayo, O. Essential oil constituents of Aframomum melegueta (Roscoe) K. Schum seeds (alligator pepper) from Nigeria. Flavour Fragr. J. 1999, 14, 109-111. [CrossRef]

30. Mohammed, A.; Gbonjubola, V.A.; Koorbanally, N.A.; Islam, M.S. Inhibition of key enzymes linked to type 2 diabetes by compounds isolated from Aframomum melegueta fruit. J. Pharm. Biol. 2017, 55, 1010-1016. [CrossRef] [PubMed]

31. Lawal, B.A.S.; Aderibigbe, A.O.; Essiet, G.A.; Essien, A.D. Hypotensive and antihypertensive effects of Aframomum melegueta seeds in humans. Int. J. Pharmacol. 2007, 3, 311-318.

32. Hedge, J.E.; Hofreiter, B.T. Determination of total carbohydrate by anthrone method. In Carbohydrate Chemistry; Whistler, R.L., Be Miller, J.N., Eds.; Academic Press: New York, NY, USA, 1962; pp. 7-8.

33. Buba, F.; Gidado, A.; Shugaba, A. Analysis of biochemical composition of honey samples from North-East Nigeria. Biochem. Anal. Biochem. 2013, 2, 1-7.

34. Ashwell, G. Determination of fructose and inulin. In Methods in Enzymol; Colowick, S.J., Kaplan, N.O., Eds.; Academic Press: New York, NY, USA, 1957; p. 75.

35. Rattanathanalerk, M.; Chiewchan, N.; Srichumpoung, W. Effect of thermal processing on the quality loss of pineapple juice. J. Food Eng. 2005, 66, 259-265. [CrossRef]

36. Methods of Analysis of Foods, Fruits and Vegetable Products. Food Safety and Standards Authority of India (FSSAI), Lab. Manual 5; Food Safety and Standards Authority of India: New Delhi, India, 2012; pp. $19-22$.

37. Evans, W.C. Trease and Evans' Pharmacognosy, 14th ed.; WB Sanders and Company Ltd.: London, UK, 1996.

38. Singleton, V.L.; Orthofe, R.; Lamuela, R.M. Analysis of total phenols and other substrates and antioxidants by means of Folin-Cocalteu reagent. Meth. Enzymol. 1999, 299, 152-178.

39. Jayaprakasha, G.K.; Singh, R.P.; Sakariah, K.K. Antioxidant activity of grape (Vitis vinifera) seed in extracts on peroxidation models in vitro. Food Chem. 2001, 73, 285-290. [CrossRef]

40. Tang, S.J.P.; Kerry, D.; Sheehan, D.J.; Morrissey, P.A. Antioxidative effect of added tea catechins on susceptibility of cooked red meat, poultry and fish to lipid oxidation. Food Res. Int. 2001, 34, 651-657. [CrossRef]

41. Oyaizu, M. Studies on products of browning reaction: Antioxidative activity of products of browning reaction prepared from glucosamine. Jpn. J. Nutr. Diet. 1986, 44, 307-315. [CrossRef]

42. Kamtekar, S.; Keer, V.; Patel, V. Estimation of phenolic content, flavonoid content, antioxidant and alpha amylase inhibitory activity of marketed polyherbal formulation. J. Appl. Pharm. Sci. 2014, 4, 61-65.

43. Oliveira, A. Sensory Evaluation of Foods. FIFC-SFOS, University of Alaska, FISH 261, Spring, 2011 . p. 33. Available online: http:/ / www.sfos.uaf.edu> fitc>lectures (accessed on 20 March 2015).

44. Amoa-Awua, W.K.; Sampson, E.; Tano-Debra, K. Growth of yeasts, lactic and acetic acid bacteria in palm wine during tapping and fermentation from felled oil palm (Elaeis guineensis) in Ghana. J. Appl. Microbiol. 2007, 102, 599-606. [CrossRef] [PubMed]

45. Stringini, M.; Comitini, F.; Taccari, M.; Ciani, M. Yeast diversity during tapping and fermentation of palm wine from Cameroon. Food Microbiol. 2009, 26, 415-420. [CrossRef] [PubMed]

46. Ouoba, L.; Kando, C.; Parkouda, C.; Sawadogo-Lingani, H.; Diawara, B.; Sutherland, J.P. The microbiology of Bandji, palm wine of Borassus akeassii from Burkina Faso: Identification and genotypic diversity of yeasts, lactic acid and acetic acid bacteria. J. Appl. Microbiol. 2012, 113, 1428-1441. [CrossRef] [PubMed]

47. Santiago-Urbina, J.A.; Verdugo-Valdez, A.G.; Ruíz-Terán, F. Physicochemical and microbiological changes during tapping of palm sap to produce an alcoholic beverage called "Taberna", which is produced in the south east of Mexico. Food Control 2013, 33, 58-62. [CrossRef]

48. Phaichamnan, M.; Posri, W.; Meenune, M. Quality profile of palm sugar concentrate produced in Songkhla province, Thailand. Int. Food Res. J. 2010, 17, 425-432. 
49. Karamoko, D.; Toka, D.M.; Moroh, J.-L.A.; Kouame, K.A.; Dje, K.M. HPLC determination of organic acids in palm saps throughout tapping process. Int. J. Innov. Appl. Stud. 2016, 17, 245-254.

50. Eze, M.O.; Ogan, A.U. Sugars of the unfermented sap and the wine from the oil, Elaeis guineensis, tree. Plant Foods Hum. Nutr. 1988, 38, 121-126. [CrossRef] [PubMed]

51. Carr, A.C.; Frei, B. Towards a new recommended dietary allowance for vitamin $\mathrm{C}$ based on antioxidant and health effects in humans. Am. J. Clin. Nutr. 1999, 69, 1086-1107. [CrossRef] [PubMed]

52. Bogdanov, S. Honey Composition. In The Honey Book; Chapter 5. Reproduced in Bee Product Science, 2009. Available online: www.bee-hexagon.net (accessed on 5 May 2011).

53. Huang, D.; Ou, B.; Prior, R.L. The chemistry behind antioxidant capacity assays. J. Agric. Food Chem. 2005, 53, 1841-1856. [CrossRef] [PubMed]

54. Proteggente, A.R.; Pannala, A.S.; Paganga, G.; Van de Buren, L.; Wagner, E.; Wiseman, S.; Van de Put, F.; Decombe, C.; Rice-Evans, C.A. The antioxidant activity of regularly consumed vegetables reflects their phenolic and vitamin C composition. Free Radic. Res. 2002, 36, 217-233. [CrossRef] [PubMed]

55. Anhe, F.F.; Desjardins, Y.; Pilon, G.; Dudonne, S.; Genovese, M.I.; Lajolo, F.M.; Marette, A. Polyphenols and type 2 diabetes: A prospective review. Pharm. Nutr. 2013, 1, 105-114. [CrossRef]

56. Marti, N.; Mena, P.; Canovas, A.; Micol, V.; Saura, D. Vitamin C and the role of citrus juices as functional food. Nat. Product Commun. 2009, 4, 677-700.

57. Eskin, N.A.M.; Henderson, H.M.; Townsend, R.J. Browning reactions in foods. In Biochemistry of Foods; Academic Press: New York, NY, USA, 1971; p. 99.

58. Borenstein, B. Vitamins and amino acids. In Handbook of Food Additives, 2nd ed.; CRC Press: Boca Raton, FL, USA, 1972; pp. 85-114.

59. Pękal, A.; Pyrzynska, K. Effect of $\mathrm{pH}$ and metal ions on DPPH radical scavenging activity of tea. Int. J. Food Sci. Nutr. 2015, 66, 48-62.

60. Dawidowicz, A.L.; Olsowy, M. Mechanism change in estimating of antioxidant activity of phenolic compounds. Talanta 2012, 97, 312-317. [CrossRef] [PubMed]

61. Seeram, N.P.; Aviram, M.; Zhang, Y.; Henning, S.M.; Feng, L.; Dreher, M.; Heber, D. Comparison of antioxidant potency of commonly consumed polyphenol-rich beverages in the United States. J. Agric. Food Chem. 2008, 56, 1415-1422. [CrossRef] [PubMed]

62. Anon. pH values of food products. Food Eng. 1962, 34, 98-99.

63. Noble, A.C. Why do wines taste bitter and feel astringent? In Chemistry of Wine Flavour: ACS Symposium Series 714; Waterhouse, A.L., Ebeler, S., Eds.; American Chemical Society: Washington, DC, USA, 1998; pp. 156-165. 